\title{
Blunted Hormone Responses to Ipsapirone are Associated with Trait Impulsivity in Personality Disorder Patients
}

\author{
Michael J Minzenberg*,1,2, Robert Grossman', Antonia S New ${ }^{1,2}$, Vivian Mitropoulou', Rachel Yehuda',2, \\ Marianne Goodman ${ }^{1,2}$, Diedre A Reynolds ${ }^{3}$, Jeremy M Silverman', Emil F Coccaro ${ }^{4}$, Sue Marcus ${ }^{5}$ \\ and Larry J Siever ${ }^{1,2}$ \\ 'Department of Psychiatry, The Mount Sinai School of Medicine, New York, NY, USA; ${ }^{2}$ Department of Psychiatry, The Bronx Veterans Affairs \\ Administration, Bronx, NY, USA; ${ }^{3}$ Department of Psychiatry, Baystate Medical Center, Springfield, MA, USA; ${ }^{4}$ Department of Psychiatry, University \\ of Chicago Pritzker School of Medicine, Chicago, IL, USA; ${ }^{5}$ Department of Psychiatry and Department of Biomathematics, The Mount Sinai School \\ of Medicine, New York, NY, USA
}

\begin{abstract}
Impulsive aggression is associated with central serotonergic dysfunction. Animal models particularly implicate the 5-HT IA receptor in this behavior. We tested the hypothesis that central 5-HTIA receptor function is impaired in impulsive aggressive personality disorder patients. A total of 52 individuals with DSM-III-R personality disorders, all medically healthy adult outpatients without concurrent psychiatric medication treatment, underwent serial plasma cortisol, prolactin, and temperature measurements before and after ipsapirone $20 \mathrm{mg}$ oral administration. Subjects completed self-report measures of impulsivity, hostility, depression and anxiety, and childhood maltreatment. Stepwise regression analysis revealed impulsivity alone among symptom measures to be associated with significantly decreased peak cortisol and prolactin responses. Diagnoses of borderline personality disorder (BPD) and intermittent explosive disorderrevised (IED-R) were associated with significantly increased and decreased cortisol responses, respectively. However, post hoc analyses indicated that impulsivity was significantly negatively correlated with cortisol responses in the BPD group, and may mediate the association of both BPD and IED-R with altered cortisol responses. Temperature response was associated with neither diagnostic nor symptom measures. Neither diagnostic nor dimensional measures of depression or anxiety, nor severity of childhood maltreatment, were significantly associated with cortisol, prolactin, or temperature responses. Impulsivity is related to impaired function at (or downstream to) postsynaptic 5-HT IA receptors, and this relationship may be partly responsible for the association of impaired serotonergic function with diagnoses such as BPD and IED-R. In addition, $\mathrm{D}_{2}$ receptor dysfunction may play a role in impulsivity, whereas $5-H T_{\text {IA }}$ cell-body autoreceptor function may be spared in these disorders.

Neuropsychopharmacology (2006) 31, 197-203. doi:I0.1038/sj.npp. I 300853; published online 3 August 2005
\end{abstract}

Keywords: serotonin; 5-HT IA receptor; cortisol; prolactin; impulsivity; borderline personality disorder

\section{INTRODUCTION}

\section{5- $\mathrm{HT}_{1 \mathrm{~A}}$ Receptor Function in Impulsive Aggression}

Considerable evidence has accumulated showing that impulsive and aggressive behaviors across psychiatric diagnoses are associated with impaired central serotonergic function (reviewed in Lee and Coccaro, 2001). The 5- $\mathrm{HT}_{1 \mathrm{~A}}$ receptor in particular has been implicated in rodent models, as administration of selective $5-\mathrm{HT}_{1 \mathrm{~A}}$ receptor agonists (such as the azapirone ipsapirone) leads to decreased

\footnotetext{
*Correspondence: Dr MJ Minzenberg, Department of Psychiatry, $\mathrm{OOMH}$, Bronx Veterans Affairs Medical Center, 130 West Kingsbridge Road, Bronx, NY 10468, USA, Tel: + I $7185849000 \times 3844$, Fax: + I 718 364-3576; E-mail: michael.minzenberg@mssm.edu Received I4 March 2005; revised 6 June 2005; accepted 23 June 2005 Online publication: 29 June 2005 at http://www.acnp.org/citations/ Npp062905050 I 78/default.pdf
}

aggressive behavior in several rodent models of offensive aggression (Bell and Hobson, 1994; Olivier et al, 1995). This evidence suggests that individuals with impulsive aggressive behavior may exhibit functional impairment of central $5-\mathrm{HT}_{1 \mathrm{~A}}$ receptors. The functional status of central $5-\mathrm{HT}_{1 \mathrm{~A}}$ receptors can be assessed in humans in vivo by means of elevated plasma cortisol and hypothermic responses to exogenous $5-\mathrm{HT}_{1 \mathrm{~A}}$ receptor agonists. The first effect is thought to be due to postsynaptic $5-\mathrm{HT}_{1 \mathrm{~A}}$ receptor activation on hypothalamic cells that release corticotrophin releasing factor (Fuller, 1992). The second effect may be due to activation of either postsynaptic $5-\mathrm{HT}_{1 \mathrm{~A}}$ receptors and/or cell-body $5-\mathrm{HT}_{1 \mathrm{~A}}$ autoreceptors that inhibit serotonergic neuronal action potential generation (Cowen et al, 1990). In addition, the azapirones also stimulate increases in plasma prolactin, an effect mediated by either post-synaptic $5-\mathrm{HT}_{1 \mathrm{~A}}$ receptor activation or dopamine-2 $\left(\mathrm{D}_{2}\right)$ receptor antagonism (Meltzer et al, 1991). Elevations in circulating cortisol 
and (more variably) prolactin can be reliably demonstrated in healthy human subjects after oral administration of ipsapirone (Lesch et al, 1989, 1990; Kahn et al, 1994; Cleare et al, 1998).

Using this paradigm, self-reported aggressiveness (measured with the Buss-Durkee Hostility Inventory, BDHI) has been associated with impaired cortisol response to ipsapirone in both healthy subjects (Cleare and Bond, 2000) and personality disordered individuals (Coccaro et al, 1995). In addition, self-reported aggressiveness has been associated with blunted prolactin response to buspirone (Coccaro et al, 1990) and ipsapirone (Cleare and Bond, 2000), disinhibition has been associated with blunted prolactin response to ipsapirone (Netter et al, 1996), and borderline personality disorder (BPD) has been associated with blunted prolactin response to flesinoxan (an agent like the azapirones, with 5- $\mathrm{HT}_{1 \mathrm{~A}}$ agonist and $\mathrm{D}_{2}$ antagonist activity) (Hansenne et al, 2002). However, others have found increased cortisol responses to ipsapirone, in association with aggression (Netter et al, 1999) and active mania (Yatham et al, 1999), and to meta-chlorophenylpiperazine ( $m$-CPP, an agent with multiple serotonergic actions (Gatch, 2003)), in association with BPD (Hollander et al, 1994). A few studies have found no association of cortisol response to ipsapirone in relation to either trait anger (Klaasen et al, 2002), disinhibition (Netter et al, 1996), or levels of aggressive responding on a laboratory test of interpersonal antagonism (Moeller et al, 1998), although the first two of these studies may have used suboptimal doses of ipsapirone (Kahn et al, 1994). Overall, this literature suggests that various syndromes of impulsivity and aggressive behavior involve alterations in the function of $5-\mathrm{HT}_{1 \mathrm{~A}}$ and possibly $\mathrm{D}_{2}$ receptors as well. In some of these disorders, it is also possible that other changes (eg, compensatory upregulation) may arise partly in response to deficits elsewhere in the serotonin system.

\section{The Present Study}

In the present study, we tested the hypothesis that impulsive aggression in personality disorder patients is associated with impaired function of central $5-\mathrm{HT}_{1 \mathrm{~A}}$ receptors. Among personality disorders as a group of diagnoses, some, such as BPD, are characterized by hallmark clinical features of impulsive aggression. Overall, there is a significant range of severity of these symptoms in patients with personality disorders, permitting an adequate test of the relationship of these symptoms to underlying biological measures, such as $5-\mathrm{HT}_{1 \mathrm{~A}}$ receptor function. The relative association of impulsivity and hostile/antagonistic behavior was evaluated in order to distinguish between related clinical features that are often confounded in measures of impulsive aggression. We also evaluated the relationship of personality disorder and comorbid Axis I diagnoses with altered 5- $\mathrm{HT}_{1 \mathrm{~A}}$ receptor function, with post hoc tests where appropriate to consider whether these relationships are mediated by trait measures of impulsive aggression. Childhood maltreatment history was also evaluated for association with cortisol response to ipsapirone, given the high rates of reported childhood maltreatment in personality disorder samples (Battle et al, 2004) and the association of maltreatment with HPA axis disturbances (Heim and Nemeroff, 2001). Dimensional and categorical (diagnostic) measures of depression and anxiety were also assessed, because of the association of these symptoms with altered $5-\mathrm{HT}_{1 \mathrm{~A}}$ receptor function (Lesch, 1991; Meltzer and Maes, 1995; Drevets et al, 1999), and their frequent appearance in personality disorder patients. We chose cortisol as an outcome measure rather than ACTH (although ACTH is more directly related to hypothalamic $5-\mathrm{HT}_{1 \mathrm{~A}}$ receptor activation) in order to resolve the results of this study with the foregoing literature on aggression and impulsivity, and because we have found previously that cortisol elevations are more reliably demonstrated than ACTH after ipsapirone administration to healthy subjects (Kahn et al, 1994).

\section{SUBJECTS AND METHODS}

\section{Subjects}

Individuals with DSM-defined personality disorders $(n=52)$ were recruited primarily from the community but also by referral from clinician colleagues in the greater New York City region. This group had a mean age of $37.3 \pm 9.4$ years and was $69 \%$ male. Inclusion criteria included ages $>18$ and $<60$, no significant medical illness, including no history of neurological illness or head injury. All subjects were within $20 \%$ of their ideal body weight (according to a standard health information chart published by Signa Health). All female subjects were studied in the first 10 days of their menstrual cycle, and none were currently taking oral contraceptive medication. A single female subject was postmenopausal at study; all results remained unchanged upon repeat analyses with this subject excluded (data not shown). Personality disorder subjects were excluded if they had lifetime co-morbid diagnoses of a primary psychotic disorder, bipolar affective disorder type I, or substance dependence. No subjects met substance abuse criteria within 6 months of study. Over $80 \%$ of this sample had never been treated with psychiatric medication. All subjects who were in current treatment with psychiatric medication at study entry had a minimum 2-week (or five half-lives) medication wash-out period prior to participation in the experimental protocol. Subjects were also queried about recent alcohol use and excluded from participation if they endorsed use just prior to the study procedure. All subjects underwent diagnostic assessment with the Structured Interview for DSM-III-R Personality Disorders (SIDP-R) (Pfohl et al, 1989). A total of 26 subjects met criteria for one or more cluster A personality disorders, 19 for cluster B disorders other than BPD, and 51 for cluster $\mathrm{C}$ disorders; the mean number of personality disorder diagnoses was $3.2 \pm 1.7$. Axis I disorders were evaluated using the Structured Clinical Interview for DSM-IV Axis I (SCID-I) (First et al, 1995). In addition, a module was employed for intermittent explosive disorder-revised (Coccaro et al, 1998). Consensus diagnoses were arrived at with the assistance of an expert diagnostician (JS). Frequencies of BPD and Axis I diagnoses are indicated in the Statistical Analysis section. Clinical traits of Impulsivity, Hostility, Depression, and Anxiety were assessed with the Barratt Impulsivity Scale - 11th version (Patton et al, 1995), BussDurkee Hostility Inventory (BDHI) (Buss and Durkee, 1957), Hamilton Depression Scale (Hamilton, 1960), and Spielberger State-Trait Anxiety Inventory (STAI) (Spielberger 
et al, 1983), respectively. Childhood maltreatment history was assessed with the Childhood Trauma Questionnaire (CTQ, 25-item version) (Bernstein and Fink, 1998). Informed consent was obtained prior to all study procedures, subject confidentiality was maintained throughout, and procedures were carried out in accordance with the Declaration of Helsinki and the Mount Sinai IRB.

\section{Ipsapirone Probe}

Subjects were admitted in a fasting condition to the Mount Sinai General Clinical Research Center at 0800, and maintained on NPO status from midnight of the day prior to the study, through the completion of the procedure. The room temperature was maintained between 66 and $75^{\circ} \mathrm{F}$. Following placement of an intravenous line, kept patent by a slow infusion of normal saline, the subjects were placed on bedrest in a quiet room with the only activity being the entry and procedural activity of the investigator. At 1000, participants were administered a $20 \mathrm{mg}$ dose of ipsapirone orally. Blood samples and vital signs were collected at $15 \mathrm{~min}$ intervals from minus $60 \mathrm{~min}$ to plus $210 \mathrm{~min}$ following administration of ipsapirone. Samples were stored in a $-80^{\circ} \mathrm{C}$ freezer until their analysis for cortisol and prolactin via standard radioimmunoassay technique.

The intra- and interassay coefficients of variation for assay of these hormones are 6 and $10 \%$ respectively for cortisol, and 1.8 and $3.9 \%$ respectively for prolactin (Koenigsberg et al, 2004). Our dependent measures were maximum delta-peak for both cortisol and prolactin (DeltaCRT and Delta-PRL), that is, peak hormone level following ipsapirone minus baseline. Area under the curve was also calculated for hormone levels following ipsapirone and results were similar to delta-peak hormone responses (data not shown). Temperature response to ipsapirone was computed as the maximal change in temperature (baseline minus nadir, ${ }^{\circ} \mathrm{F}$ ) following ipsapirone administration.

\section{Statistical Analysis}

We first assessed the effects of age, sex, and body weight on the outcome measures of temperature and hormone levels, each at baseline and in response to ipsapirone, in order to address potential confounding factors. We then conducted a series of stepwise multiple regression analyses to evaluate the association of both dimensional (trait) and categorical (diagnostic) measures as independent variables, each first with baseline measures and then with responses to ipsapirone. We have chosen the present analytic approach for several reasons: (1) with repeated-measures ANOVA, the variance is typically misestimated due to the variable correlations between repeated measures typically found in physiology research (Kristensen and Hansen, 2004); (2) change scores are also commonly utilized in longitudinal treatment response designs in psychiatry (Ekstrom et al, 1990), and, as summary measures, have an advantage of ease of interpretability (Hennen, 2003); and (3) stepwise regression allows for an 'omnibus' test of association of a number of predictor variables that are hypothetically related to the dependent variable, which we are compelled to consider given the extensive diagnostic comorbidity inherent in this personality disorder sample. This approach also allows for the simultaneous evaluation of diagnostic and trait/symptom measures, and estimates of the relative portion of the variance accounted for in the dependent variables by these clinical measures. We therefore believe that this approach is reasonably valid, conservative, and comprehensive with the present data set. Trait measures included Impulsivity (mean $38.7 \pm 13.0$ ), Hostility (mean 35.3 \pm 14.3 ), Depression (mean 15.0 \pm 7.8 ), Trait Anxiety (mean $50.5 \pm 13.2$ ), and State Anxiety (mean $42.8 \pm$ 13.0). Childhood maltreatment (CTQ total score, mean $49.8 \pm 17.6)$ was also considered in this analysis. In the stepwise regression analysis of diagnoses, current DSMIII-R diagnoses of BPD $(n=21)$, IED-R $(n=21)$, major depressive disorder $(n=25)$, dysthymic disorder $(n=10)$, depression not otherwise specified $(n=1)$, post-traumatic stress disorder $(n=6)$, obsessive-compulsive disorder $(n=6)$, panic disorder $(n=6)$, and generalized anxiety disorder $(n=12)$ were evaluated, although the full range of Axis I disorders were addressed in the diagnostic evaluation (15 subjects were comorbid for BPD and IED-R). Total numbers of diagnoses per subject of personality disorders (mean 3.2 \pm 1.7 ), mood disorders (mean $0.7 \pm 0.6$ ), and anxiety disorders (mean $0.6 \pm 0.8$ ) were also considered in this analysis. Where demographic variables were associated with outcome measures, or where diagnostic or trait variables were associated with baseline measures, the demographic variables or baseline measures were then entered as independent variables to the regression analyses of ipsapirone response measures. This strategy was used to control for possible confounding effects of either demographic differences or varying baseline measures on the ipsapirone response measures. All independent variables were entered in a forward manner into their respective regression models, with probabilities to enter and remove variables set at $p=0.05$ and 0.10 , respectively, for all analyses.

\section{RESULTS}

\section{Cortisol}

The mean baseline cortisol level was $12.1 \pm 4.8 \mu \mathrm{g} / \mathrm{dl}$, and mean peak cortisol response to ipsapirone was $13.5 \pm 8.0$ $\mu \mathrm{g} / \mathrm{dl}$. Age was associated with neither baseline cortisol (Pearson's $r=-0.03$ ) nor cortisol response to ipsapirone $(r=-0.02)$. Body weight was associated with neither baseline cortisol $(r=-0.03, p=0.9)$ nor cortisol response to ipsapirone $(r=-0.07, p=0.6)$. In addition, female subjects were not significantly different from male subjects on either baseline cortisol $(12.7 \pm 4.5 v s \quad 11.8 \pm 5.0 \mu \mathrm{g} / \mathrm{dl}$; $t=0.61, \mathrm{df}=50, p=0.55)$ or cortisol response to ipsapirone $(15.6 \pm 8.4 v s 12.5 \pm 7.7 \mu \mathrm{g} / \mathrm{dl} ; t=1.29, \mathrm{df}=50, p=0.20)$.

In stepwise regression analysis, neither dimensional nor diagnostic measures were associated with baseline cortisol levels. Subsequently, in the stepwise regression analysis of dimensional variables, Impulsivity was the single significant predictor of decreased cortisol response to ipsapirone (adjusted $R^{2}=0.072 ; t=-2.22, p=0.031$ ). Dimensional Hostility, Depression and Anxiety symptoms, and Childhood Maltreatment were not associated with significant effects on cortisol response. Stepwise regression analysis of diagnostic variables revealed two significant diagnostic 


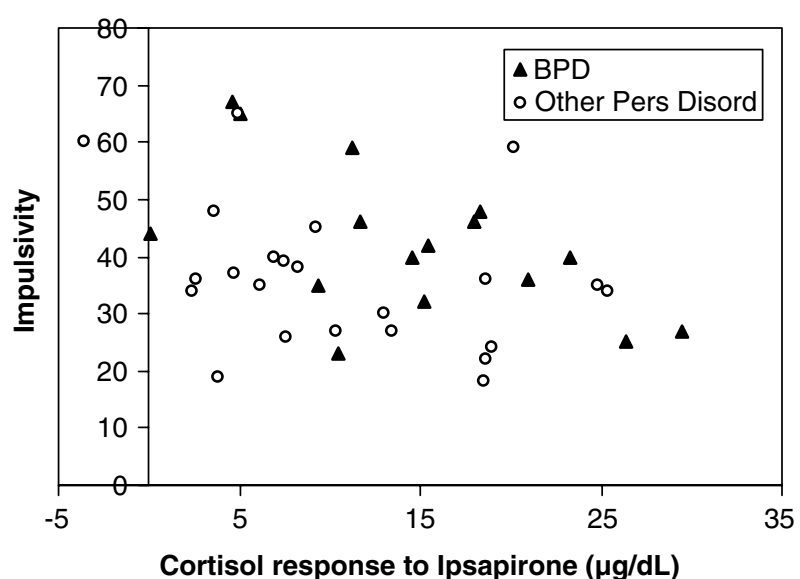

Figure I Relationship of impulsivity to peak plasma cortisol response to ipsapirone in personality disorder subjects.

predictors of cortisol response to ipsapirone (total adjusted $\left.R^{2}=0.176\right): \operatorname{BPD}(t=2.71, p=0.009)$ and IED-R $(t=-3.41$, $p=0.001)$. The mean cortisol response for BPD $v s$ nonBPD subjects was $14.8 \pm 7.5 \mu \mathrm{g} / \mathrm{dl}$ and $12.6 \pm 8.3 \mu \mathrm{g} / \mathrm{dl}$, respectively; and for IED-R $v s$ nonIED-R subjects were $10.6 \pm 7.2$ and $15.4 \pm 8.1 \mu \mathrm{g} / \mathrm{dl}$, respectively. The results of the regression analyses indicate that BPD was associated with significantly increased cortisol response whereas IED-R was associated with significantly decreased cortisol response to ipsapirone. However, cortisol response to ipsapirone was negatively correlated with impulsivity in the BPD group (Pearson's $r=-0.57, p=0.021$ ) (Figure 1). No mood or anxiety disorder diagnoses were associated with significant effects on cortisol response, nor were the total number of personality disorder, mood disorder or anxiety disorder diagnoses per subject. We also conducted a post hoc stepwise regression analysis to evaluate the relative association of those diagnostic and dimensional variables that were found to be significant predictors of cortisol response in the regression analyses just described. $B P D$, IED-R, and Impulsivity scores were entered to the regression model in the same forward manner as with other analyses. This analysis revealed a single significant predictor, Impulsivity (adjusted $R^{2}=0.072 ; t=-2.22$, $p=0.031)$. BPD and IED-R effects in this regression model were reduced to nonsignificance $(t=1.52, p=0.134$, and $t=-1.55, p=0.127$, respectively). These findings appear to indicate that there was a negative relationship between Impulsivity and cortisol response to ipsapirone in the BPD group, although the BPD group on average showed cortisol responses that were shifted upward relative to the rest of the personality disorder sample (Figure 1). These findings also suggest that the effects of BPD and IED diagnoses on cortisol response to ipsapirone are largely mediated by dimensional impulsivity.

\section{Prolactin}

The mean baseline prolactin level was $7.7 \pm 3.6 \mathrm{ng} / \mathrm{ml}$, and mean prolactin response to ipsapirone was $3.6 \pm 7.0 \mathrm{ng} / \mathrm{ml}$. Age was inversely related to baseline prolactin $(r=-0.37$, $p=0.008$ ) but not prolactin response to ipsapirone $(r=0.02)$. Body weight was associated with neither baseline prolactin $(r=-0.24, p=0.09)$ nor prolactin response to ipsapirone $(r=0.17 p=0.23)$. Female subjects had significantly higher baseline prolactin levels than males $(10.8 \pm 4.0$ vs $6.3 \pm 2.4 \mathrm{ng} / \mathrm{ml})(t=5.00, \mathrm{df}=50, p<0.0005)$ but prolactin levels in response to ipsapirone that were not significantly different from males $(1.6 \pm 5.4$ vs $4.5 \pm$ $7.5 \mathrm{ng} / \mathrm{ml})(t=1.41, \mathrm{df}=50, p=0.17)$. In stepwise regression analyses, symptom measures were not associated with baseline prolactin; however, Impulsivity was significantly associated with blunted prolactin response to ipsapirone (adjusted $R^{2}=0.10 ; t=-2.58, p=0.013$ ). Age and sex did not make significant additional contributions to prolactin response to ipsapirone with Impulsivity entered to the regression model. No diagnoses were significantly associated with prolactin either at baseline or in response to ipsapirone.

\section{Temperature}

Age was inversely related to baseline temperature $(r=-0.33, p=0.023)$ but was not related to temperature response to ipsapirone $(r=-0.09, p=0.5)$. Female subjects had a significantly higher baseline temperature than male subjects $\left(98.0 \pm 0.5^{\circ} \mathrm{F}\right.$ vs $\left.97.4 \pm 0.6^{\circ} \mathrm{F}\right) \quad(t=3.76, \quad \mathrm{df}=49$, $p<0.0005$ ) but a temperature response to ipsapirone that was not significantly different from male subjects $\left(0.89 \pm 0.76^{\circ} \mathrm{F}\right.$ vs $\left.0.66 \pm 0.78^{\circ} \mathrm{F}\right) \quad(t=-0.98, \mathrm{df}=49$, $p=0.33$ ). In regression analyses, only BPD among the diagnostic and symptom measures was associated with baseline temperature (adjusted $R^{2}=0.12 ; \quad t=3.21$, $p=0.002$ ). However, with baseline temperature entered to the stepwise regression analysis of temperature response to ipsapirone, neither BPD nor other diagnoses nor symptom measures were associated with temperature response to ipsapirone.

\section{DISCUSSION}

In this study, we evaluated the association of trait and diagnostic measures of impulsive aggression with impaired central $5-\mathrm{HT}_{1 \mathrm{~A}}$ receptor function, measured by plasma cortisol, prolactin, and hypothermic responses to ipsapirone, in an outpatient sample of 52 individuals with personality disorder diagnoses. We found that trait impulsivity is associated with decreased postsynaptic 5$\mathrm{HT}_{1 \mathrm{~A}}$ (and possibly $\mathrm{D}_{2}$ ) receptor responsivity to ipsapirone, and may mediate the association of BPD and IED-R with altered $5-\mathrm{HT}_{1 \mathrm{~A}}$ receptor function. Categorical and dimensional measures of depression and anxiety were not responsible for these associations, nor was the severity of childhood maltreatment history. In addition, no evidence was found for altered responsivity of the cell-body $5-\mathrm{HT}_{1 \mathrm{~A}}$ autoreceptor.

These findings are consistent with the evidence from animal models and clinical serotonergic challenge studies in humans, which indicate that impulsive and aggressive behavior is associated with impaired central $5-\mathrm{HT}_{1 \mathrm{~A}}$ receptor function. The present experimental paradigm assesses postsynaptic $5-\mathrm{HT}_{1 \mathrm{~A}}$ receptors in the hypothalamus, a brain region that is associated with social and 
emotional behavior, including aggressive behavior. However, these findings may additionally be consistent with a more general postsynaptic $5-\mathrm{HT}_{1 \mathrm{~A}}$ receptor mediation of the blunted serotonergic responses observed in brain imaging experiments in frontal cortical regions that are also responsible for emotional-behavioral integration, such as the anterior cingulate and ventral prefrontal cortex (Siever et al, 1999; Soloff et al, 2000; New et al, 2002). We also found that hostility per se is not significantly associated with altered $5-\mathrm{HT}_{1 \mathrm{~A}}$ receptor function, when the effects of impulsivity are accounted for in the regression model. Antagonistic thoughts and emotions are confounded with behavioral dyscontrol to some extent in measures such as the Buss-Durkee Hostility Inventory, and therefore we used a separate measure of impulsivity (Barratt Impulsivity Scale) to contrast the negative moods from the behavioral dyscontrol, both of which are exhibited in the syndrome of impulsive aggression. The results suggest that impulsivity is a specific consequence of impaired $5-\mathrm{HT}_{1 \mathrm{~A}}$ receptor function, and that hostility may be related to disturbances at other sites within the central serotonin system, or in other monoamine systems that interact with serotonin such as the catecholamines.

Interestingly, the BPD diagnosis was associated with significantly greater cortisol response to ipsapirone, relative to subjects with other personality disorder diagnoses. A similar finding among BPD patients was reported in a study of cortisol response to $m$-CPP (Hollander et al, 1994). It is certainly possible that BPD patients exhibit relatively increased activity in the hypothalamic-pituitary-adrenal axis unrelated to the hypothalamic $5-\mathrm{HT}_{1 \mathrm{~A}}$ receptor, which would be consistent with the findings of a recent study reporting higher diurnal salivary cortisol in female BPD patients without major depression, relative to healthy controls (Lieb et al, 2004). This could result in enhanced cortisol levels in response to similar levels of hypothalamic $5-\mathrm{HT}_{1 \mathrm{~A}}$ receptor activation. Nevertheless, the negative correlation between impulsivity and cortisol response to ipsapirone in the BPD group indicates that this relationship is consistent for the BPD subjects as it is for the sample as a whole. The upward shift of cortisol response observed in the BPD group overall, relative to the other personality disorder subjects, may additionally suggest that BPD patients exhibit a relatively greater capacity for compensatory upregulation of postsynaptic $5-\mathrm{HT}_{1 \mathrm{~A}}$ receptor function. Nevertheless, we found that trait impulsivity was more closely related to cortisol response than diagnostic status. It was also the only measure associated with blunted prolactin response to ipsapirone, which may reflect altered function at the $5-\mathrm{HT}_{1 \mathrm{~A}}$ receptor and/or the $\mathrm{D}_{2}$ receptor in the hypothalamus. Taken together, these results suggest that, in a sample of individuals characterized by a categorical psychiatric diagnosis such as BPD or IED-R, exaggerated degrees of traits such as impulsivity may be the more important (or more direct) correlate of altered central serotonergic dysfunction (Minzenberg and Siever, 2005). The lack of diagnostic or symptom associations with temperature response to ipsapirone suggests that these disorders may exhibit $5-\mathrm{HT}_{1 \mathrm{~A}}$ receptor dysfunction extrinsic to serotonergic neurons themselves, as we have not found evidence for cell-body $5-\mathrm{HT}_{1 \mathrm{~A}}$ autoreceptor dysfunction in these individuals.
The functional status of central $5-\mathrm{HT}_{1 \mathrm{~A}}$ receptors has not been well studied in other impulse control disorders to date. Preliminary evidence suggests that $5-\mathrm{HT}_{1 \mathrm{~A}}$ receptor gene variation contributes a small but significant amount of variance to symptom scores for attention-deficit hyperactivity disorder (Comings et al, 2000); a variant in the $5-\mathrm{HT}_{1 \mathrm{~A}}$ receptor (due to a missense nucleotide change) has been isolated in a patient with Tourette's syndrome (Lam et al, 1996); and selective $5-\mathrm{HT}_{1 \mathrm{~A}}$ receptor agonists can reduce alcohol intake in dependent animals (De Vry, 1995). However, other investigators have found no association of the $5-\mathrm{HT}_{1 \mathrm{~A}}$ receptor gene with Tourette's syndrome (Brett et al, 1995), and increased cortisol response to ipsapirone in active mania (Yatham et al, 1999). The general role of central $5-\mathrm{HT}_{1 \mathrm{~A}}$-receptor dysfunction across impulse control disorders remains to be fully investigated. On the basis of the present evidence, we would suggest that $5-\mathrm{HT}_{1 \mathrm{~A}}$-receptor dysfunction may be a contributing factor to impulsivity across psychiatric diagnoses.

\section{Study Limitations}

We did not evaluate the basal circadian rhythms of cortisol, prolactin, or body temperature in this study. There is evidence that depression is associated with phase advances in circadian and ultradian rhythms of circulating cortisol and prolactin levels (Koenigsberg et al, 2004); this phenomenon, to our knowledge, has not been studied in the disorders presently under study. We therefore cannot rule out that observed differences in circulating hormone levels measured after ipsapirone administration are due to differences in underlying rhythmicity of basal hormone levels rather than altered responses to ipsapirone. In addition, in this study (as with many in this literature), we have measured cortisol but not adrenocorticotropin (ACTH), which is a more direct measure of hypothalamic $5-\mathrm{HT}_{1 \mathrm{~A}}$ receptor regulation of the HPA axis. Therefore, we cannot be certain that the present findings do not reflect hyporesponsivity in the adrenal cortex rather than at the hypothalamic $5-\mathrm{HT}_{1 \mathrm{~A}}$ receptor. Future investigations should ideally assess the underlying rhythmicity of circulating hormone levels, and the relative responses of ACTH and cortisol to $5-\mathrm{HT}_{1 \mathrm{~A}}$ receptor stimulation.

\section{Conclusion}

Dysfunction of the central $5-\mathrm{HT}_{1 \mathrm{~A}}$ receptor is associated with impulsive aggression in animal models and clinical studies. The present findings suggest that impulsivity may be particularly related to impaired postsynaptic $5-\mathrm{HT}_{1 \mathrm{~A}}$ (and possibly $\mathrm{D}_{2}$ ) receptor function. The trait impulsivity that is characteristic of BPD and IED may be a more significant correlate of altered $5-\mathrm{HT}_{1 \mathrm{~A}}$ receptor dysfunction than are the categorical diagnoses themselves. Future studies should take advantage of serotonergic agents with enhanced pharmacological selectivity in order to more precisely specify the dysfunction of central serotonin and the relationship of these disturbances to various syndromes of mood disturbance and behavioral dyscontrol. 


\section{ACKNOWLEDGEMENTS}

This study was funded in part by NIMH 1-RO1-MH5660601A2 and DVA 7609-28 to LJS, and R03 MR 58697-01 to RG.

\section{REFERENCES}

Battle CL, Shea MT, Johnson DM, Yen S, Zlotnick C, Zanarini MC et al (2004). Childhood maltreatment associated with adult personality disorders: findings from the Collaborative Longitudinal Personality Disorders Study. J Pers Disord 18: 193-211.

Bell R, Hobson $\mathrm{H}$ (1994). 5- $\mathrm{HT}_{1 \mathrm{~A}}$ receptor influences on rodent social and agonistic behavior: a review and empirical study. Neurosci Biobehav Rev 18: 325-338.

Bernstein DP, Fink L (1998). Childhood Trauma Questionnaire: A Retrospective Self-Report Manual. Psychological Corporation: San Antonio, TX.

Brett PM, Curtis D, Robertson MM, Gurling HM (1995). Exclusion of the 5-HT1A serotonin neuroreceptor and tryptophan oxygenase genes in a large British kindred multiply affected with Tourette's syndrome, chronic motor tics, and obsessivecompulsive behavior. Am J Psychiatry 152: 437-440.

Buss AH, Durkee A (1957). An inventory for assessing different kinds of hostility. J Consult Psychol 21: 343-349.

Cleare AJ, Forsling M, Bond AJ (1998). Neuroendocrine and hypothermic effects of $5-\mathrm{HT}_{1 \mathrm{~A}}$ receptor stimulation with ipsapirone in healthy men: a placebo-controlled study. Int Clin Psychopharmacol 13: 23-32.

Cleare AJ, Bond AJ (2000). Ipsapirone challenge in aggressive men shows an inverse correlation between $5-\mathrm{HT}_{1 \mathrm{~A}}$ receptor function and aggression. Psychopharmacology 148: 344-349.

Coccaro EF, Gabriel S, Siever LJ (1990). Buspirone challenge: preliminary evidence for a role of $5-\mathrm{HT}_{1 \mathrm{~A}}$ receptors in impulsive aggressive behavior in humans. Psychopharmacol Bull 26: 393-405.

Coccaro EF, Kavoussi RJ, Hauger RL (1995). Physiological responses to $d$-fenfluramine and ipapirone challenge correlate with indices of aggression in males with personality disorder. Int Clin Psychopharmacol 10: 177-179.

Coccaro EF, Kavoussi RJ, Berman ME, Lish JD (1998). Intermittent explosive disorder-revised: development, reliability, and validity of research criteria. Compr Psychiatry 39: 368-376.

Comings DE, Gade-Andavolu R, Gonzalez N, Wu S, Muhleman D, Blake $\mathrm{H}$ et al (2000). Comparison of the role of dopamine, serotonin, and noradrenaline genes in ADHD, ODD and conduct disorder: multivariate regression analysis of 20 genes. Clin Genet 57: 178-196.

Cowen PJ, Anderson IA, Grahame-Smith DG (1990). Neuroendocrine effects of azapirones. J Clin Psychopharmacol 10: 21S-25S.

De Vry J (1995). 5-HT1A receptor agonists: recent developments and controversial issues. Psychopharmacology (Berl) 121: 1-26.

Drevets WC, Frank E, Price JC, Kupfer DJ, Holt D, Greer PJ et al (1999). PET imaging of serotonin 1A receptor binding in depression. Biol Psychiatry 46: 1375-1387.

Ekstrom D, Quade D, Golden RN (1990). Statistical analysis of repeated measures in psychiatric research. Arch Gen Psychiatry 47: 770-772.

First MB, Spitzer RL, Gibbon M, Williams JBW, Benjamin LS (1995). User's Guide for the Structured Clinical Interview for DSM-IV Axis I (SCID-I). American Psychiatric Press: Washington, DC.

Fuller R (1992). The involvement of serotonin in regulation of pituitary-adrenocortical function. Front Neuroendocrinol 13: 250-270.

Gatch MB (2003). Discriminative stimulus effects of m-chlorophenylpiperazine as a model of the role of serotonin receptors in anxiety. Life Sci 73: 1347-1367.
Hamilton M (1960). A rating scale for depression. J Neurol Neurosurg Psychiatry 23: 56-62.

Hansenne M, Pitchot W, Pinto E, Reggers J, Scantamburlo G, Fuchs S et al (2002). 5- $\mathrm{HT}_{1 \mathrm{~A}}$ dysfunction in borderline personality disorder. Psychol Med 32: 935-941.

Heim C, Nemeroff CB (2001). The role of childhood trauma in the neurobiology of mood and anxiety disorders: preclinical and clinical studies. Biol Psychiatry 49: 1023-1039.

Hennen J (2003). Statistical methods for longitudinal research on bipolar disorders. Bipolar Disord 5: 156-168.

Hollander E, Stein DJ, DeCaria CM, Cohen L, Saoud JB, Skodol AE et al (1994). Serotonergic sensitivity in borderline personality disorder: preliminary findings. Am J Psychiatry 151: 277-280.

Kahn RS, Trestman R, Lawlor BA, Gabriel S, Davidson M, Siever L (1994). Effects of ipsapirone in healthy subjects: a dose-response study. Psychopharmacology 114: 155-160.

Klaasen T, Riedel WJ, van Praag HM, Menheere PPCA, Griez E (2002). Neuroendocrine response to meta-chlorophenylpiperazine and ipsapirone in relation to anxiety and aggression. Psychiatry Res 113: 29-40.

Koenigsberg HW, Teicher MH, Mitropoulou V, Navalta C, New AS, Trestman $\mathrm{R}$ et al (2004). 24-h monitoring of plasma norepinephrine, MHPG, cortisol, growth hormone and prolactin in depression. J Psychiatr Res 38: 503-511.

Kristensen M, Hansen T (2004). Statistical analyses of repeated measures in physiological research: a tutorial. Adv Physiol Educ 28: 2-14.

Lam S, Shen Y, Nguyen T, Messier TL, Brann M, Comings D et al (1996). A serotonin receptor gene (5HT1A) variant found in a Tourette's syndrome patient. Biochem Biophys Res Commun 219: 853-858.

Lee R, Coccaro E (2001). The neuropsychopharmacology of criminality and aggression. Can J Psychiatry 46: 35-44.

Lesch KP, Rupprecht R, Poten B, Muller U, Sohnle K, Fritze J et al (1989). Endocrine responses to 5-hydroxytryptamine-1A receptor activation by ipsapirone in humans. Biol Psychiatry 26: 203-205.

Lesch KP, Sohnle K, Poten B, Schoellnhammer G, Rupprecht R, Schulte HM (1990). Corticotropin and cortisol secretion after central 5-hydroxytryptamine-1A $\left(5-\mathrm{HT}_{1 \mathrm{~A}}\right)$ receptor activation: effects of 5-HT receptor and $\beta$-adrenoceptor antagonists. J Clin Endocrinol Metab 70: 670-674.

Lesch KP (1991). 5- $\mathrm{HT}_{1 \mathrm{~A}}$ receptor responsivity in anxiety disorders and depression. Prog Neuro-Psychopharmacol Biol Psychiatry 15: $723-733$.

Lieb K, Rexhausen JE, Kahl KG, Schweiger U, Philipsen A, Hellhammer DH et al (2004). Increased diurnal salivary cortisol in women with borderline personality disorder. J Psychiatr Res 38: 559-565.

Meltzer HY, Gudelsky GA, Lowy MT, Nash JF, Koenig JI (1991). Neuroendocrine effects of buspirone: mediation by dopaminergic and serotonergic mechanisms. In: Tunnicliff G, Eison AS, Taylor OP (eds). Buspirone: Mechanisms and Clinical Aspects. Academic Press: San Diego. pp 177-192.

Meltzer HY, Maes M (1995). Effects of ipsapirone on plasma cortisol and body temperature in major depression. Biol Psychiatry 38: 450-457.

Minzenberg MJ, Siever LJ (2005). Biochemical Endophenotypes in Borderline Personality Disorder. In: Zanarini MC (ed). Borderline Personality Disorder. Dekker: New York.

Moeller FG, Allen T, Cherek DR, Dougherty DM, Lane S, Swann AC (1998). Ipsapirone neuroendocrine challenge: relationship to aggression as measured in the human laboratory. Psychiatry Res 81: $31-38$.

Netter P, Hennig J, Roed IS (1996). Serotonin and dopamine as mediators of sensation seeking behavior. Neuropsychobiology 34: 155-165. 
Netter P, Hennig J, Rohrmann S (1999). Psychobiological differences between the aggression and psychoticism dimension. Pharmacopsychiatry 32: 5-12.

New AS, Hazlett EA, Buchsbaum MS, Goodman M, Reynolds D, Mitropoulou V et al (2002). Blunted prefrontal cortical 18fluorodeoxyglucose positron emission tomography response to meta-chlorophenylpiperazine in impulsive aggression. Arch Gen Psychiatry 59: 621-629.

Olivier B, Mos J, van Oorschot R, Hen R (1995). Serotonin receptors and animal models of aggressive behavior. Pharmacopsychiatry 28S: 80-90.

Patton JH, Stanford MS, Barratt ES (1995). Factor structure of the Barratt impulsiveness scale. J Clin Psychol 51: 768-774.

Pfohl BM, Blum N, Zimmerman M, Stangl D (1989). Structured Interview for DSM-III-R Personality: SIDP-R. Author: Iowa City, IA.
Siever LJ, Buchsbaum MS, New AS, Spiegel-Cohen J, Wei T, Hazlett EA et al (1999). d,l-Fenfluramine response in impulsive personality disorder assessed with $\left[{ }^{18} \mathrm{~F}\right]$ flurodeoxyglucose positron emission tomomgraphy. Neuropsychopharmacology 20: 413-423.

Soloff PH, Meltzer CC, Greer PJ, Constantine D, Kelly TM (2000). A fenfluramine-activated FDG-PET study of borderline personality disorder. Biol Psychiatry 47: 540-547.

Spielberger CD, Gorsuch RC, Lushene RE, Vagg PR, Jacobs GA (1983). Manual for the State-Trait Anxiety Inventory. Consulting Psychologists Press: Palo Alto, CA.

Yatham LN, Shiah IS, Lam RW, Tam EM, Zis AP (1999). Hypothermic, ACTH, and cortisol responses to ipsapirone in patients with mania and healthy controls. J Affect Disord 54: 295-301. 